\title{
Guanidine Methods for Total RNA \\ Preparation
}

Three different methods for RNA preparation using guanidine are presented in this unit - a single-step isolation method employing liquid-phase separation to selectively extract total RNA from tissues and cultured cells (see Basic Protocol) and two methods that rely on a $\mathrm{CsCl}$ step gradient to isolate total RNA (see Alternate Protocols 1 and 2).

\section{SINGLE-STEP RNA ISOLATION FROM CULTURED CELLS OR TISSUES}

Cultured cells or tissues are homogenized in a denaturing solution containing $4 \mathrm{M}$ guanidine thiocyanate. The homogenate is mixed sequentially with $2 \mathrm{M}$ sodium acetate $(\mathrm{pH} 4)$, phenol, and finally chloroform/isoamyl alcohol or bromochloropropane. The resulting mixture is centrifuged, yielding an upper aqueous phase containing total RNA. In this single-step extraction the total RNA is separated from proteins and DNA that remain in the interphase and in the organic phase. Following isopropanol precipitation, the RNA pellet is redissolved in denaturing solution (containing $4 \mathrm{M}$ guanidine thiocyanate), reprecipitated with isopropanol, and washed with $75 \%$ ethanol.

\section{Materials}

Denaturing solution (see recipe)

$2 \mathrm{M}$ sodium acetate, $\mathrm{pH} 4$ (see recipe)

Water-saturated phenol (see recipe)

49:1 (v/v) chloroform/isoamyl alcohol or bromochloropropane

$100 \%$ isopropanol

75\% ethanol (prepared with DEPC-treated water; UNIT 4.1)

DEPC-treated water (UNIT 4.1) or freshly deionized formamide (see recipe)

Glass Teflon homogenizer

5-ml polypropylene centrifuge tube

Sorvall SS-34 rotor (or equivalent)

CAUTION: Phenol is a poison and causes burns. When handling phenol, use gloves and eye protection.

NOTE: Carry out all steps at room temperature unless otherwise stated.

\section{Homogenize cells}

1a. For tissue: Add $1 \mathrm{ml}$ denaturing solution per $100 \mathrm{mg}$ tissue and homogenize with a few strokes in a glass Teflon homogenizer.

1b. For cultured cells: Either centrifuge suspension cells and discard supernatant, or remove the culture medium from cells grown in monolayer cultures. Add $1 \mathrm{ml}$ denaturing solution per $10^{7}$ cells and pass the lysate through a pipet seven to ten times.

Do not wash cells with saline. Cells grown in monolayer cultures can be lysed directly in the culture dish or flask.

The procedure can be carried out in sterile, disposable, round-bottom polypropylene tubes with caps; no additional treatment of the tubes is necessary. Before using, test if the tubes can withstand centrifugation at $10,000 \times g$ with the mixture of denaturing solution and phenol/chloroform.

2. Transfer the homogenate into a 5-ml polypropylene tube. Add $0.1 \mathrm{ml}$ of $2 \mathrm{M}$ sodium acetate, $\mathrm{pH} \mathrm{4}$, and mix thoroughly by inversion. Add $1 \mathrm{ml}$ water-saturated phenol,

Contributed by Robert E. Kingston, Piotr Chomczynski, and Nicoletta Sacchi

Current Protocols in Molecular Biology (1996) 4.2.1-4.2.9

Copyright $\odot 2000$ by John Wiley \& Sons, Inc.
UNIT 4.2

BASIC

PROTOCOL
Preparation and Analysis of RNA

4.2.1

Supplement 36 
mix thoroughly, and add $0.2 \mathrm{ml}$ of $49: 1$ chloroform/isoamyl alcohol or bromochloropropane. Mix thoroughly and incubate the suspension $15 \mathrm{~min}$ at $0^{\circ}$ to $4^{\circ} \mathrm{C}$.

Make sure that caps are tightly closed when mixing. The volumes used are per $1 \mathrm{ml}$ denaturing solution.

Bromochloropropane is less toxic than chloroform and its use for phase separation decreases possibility of contaminating RNA with DNA (Chomczynski and Mackey, 1995).

3. Centrifuge $20 \mathrm{~min}$ at $10,000 \times g(9000 \mathrm{rpm}$ in SS-34 rotor $), 4^{\circ} \mathrm{C}$. Transfer the upper aqueous phase to a clean tube.

The upper aqueous phase contains the RNA, whereas the DNA and proteins are in the interphase and lower organic phase. The volume of the aqueous phase is $\sim 1 \mathrm{ml}$, equal to the initial volume of denaturing solution.

\section{Isolate RNA}

4. Precipitate the RNA by adding $1 \mathrm{ml}(1 \mathrm{vol})$ of $100 \%$ isopropanol. Incubate the samples $30 \mathrm{~min}$ at $-20^{\circ} \mathrm{C}$. Centrifuge $10 \mathrm{~min}$ at $10,000 \times g, 4^{\circ} \mathrm{C}$, and discard supernatant.

For isolation of RNA from tissues with a high glycogen content (e.g., liver), a modification of the single-step method is recommended to diminish glycogen contamination (Puissant and Houdebine, 1990). Following this isopropanol precipitation, wash out glycogen from the RNA pellet by vortexing in $4 \mathrm{M} \mathrm{LiCl}$. Sediment the insoluble RNA 10 min at $5000 \times \mathrm{g}$. Dissolve the pellet in denaturing solution and follow the remainder of the protocol.

5. Dissolve the RNA pellet in $0.3 \mathrm{ml}$ denaturing solution and transfer into a $1.5-\mathrm{ml}$ microcentrifuge tube.

6. Precipitate the RNA with $0.3 \mathrm{ml}(1 \mathrm{vol})$ of $100 \%$ isopropanol for $30 \mathrm{~min}$ at $-20^{\circ} \mathrm{C}$. Centrifuge $10 \mathrm{~min}$ at $10,000 \times \mathrm{g}, 4^{\circ} \mathrm{C}$, and discard supernatant.

7. Resuspend the RNA pellet in $75 \%$ ethanol, vortex, and incubate 10 to $15 \mathrm{~min}$ at room temperature to dissolve residual amounts of guanidine contaminating the pellet.

8. Centrifuge $5 \mathrm{~min}$ at $10,000 \times g, 4^{\circ} \mathrm{C}$, and discard supernatant. Dry the RNA pellet in a vacuum for $5 \mathrm{~min}$.

Do not let the RNA pellet dry completely, as this greatly decreases its solubility. Avoid drying the pellet by centrifugation under vacuum. Drying is not necessary for solubilization of RNA in formamide.

9. Dissolve the RNA pellet in 100 to $200 \mu 1$ DEPC-treated water or freshly deionized formamide by passing the solution a few times through a pipe tip. Incubate 10 to 15 min at $55^{\circ}$ to $60^{\circ} \mathrm{C}$. Store RNA dissolved in water at $-70^{\circ} \mathrm{C}$ and RNA dissolved in formamide at either $-20^{\circ}$ or $-70^{\circ} \mathrm{C}$.

$R N A$ dissolved in formamide is protected from degradation by RNase and can be used directly for formaldehyde-agarose gel electrophoresis in northern blotting (Chomczynski, 1992). However, before use in RT-PCR, RNA should be precipitated from formamide by adding 4 vol ethanol and centrifuging 5 min at 10,000 $\times g$.

\section{Quantitate RNA}

10. Quantitate RNA by diluting $5 \mu \mathrm{lin} 1 \mathrm{ml}$ alkaline water and reading the $A_{260}$ and $A_{280}$ (APPENDIX 3D).

Water used for spectrophotometric measurement of RNA should have $p H>7.5$. Acidic $p H$ affects the UV absorption spectrum of RNA and significantly decreases its $A_{260} / A_{280}$ ratio (Willfinger et al., 1996). Typically, distilled water has $\mathrm{pH}<6$. Adjust water to a slightly alkaline $\mathrm{pH}$ by adding concentrated $\mathrm{Na}_{2} \mathrm{HPO}_{4}$ solution to a final concentration of $1 \mathrm{mM}$. 


\section{CsCI PURIFICATION OF RNA FROM CULTURED CELLS}

Cells are washed free of medium and are then lysed by placing them in a $4 \mathrm{M}$ guanidine solution. The viscosity of the solution is reduced by drawing the lysate through a 20-G needle and the RNA is pelleted through a $\mathrm{CsCl}$ step gradient. The supernatant fluid from this gradient is then carefully removed to allow complete separation of RNA, found in the pellet, from contaminating DNA and protein. Finally, the RNA in the pellet is dissolved, ethanol precipitated, and quantitated spectrophotometrically at $A_{260}$.

Additional Materials (also see Basic Protocol)

Phosphate-buffered saline (PBS; APPENDIX 2)

Guanidine solution (see recipe)

5.7 M cesium chloride $(\mathrm{CsCl})$, DEPC-treated (see recipe)

TES solution (see recipe)

$3 \mathrm{M}$ sodium acetate, $\mathrm{pH} 5.2$ (APPENDIX 2)

$100 \%$ ethanol

Rubber policeman

6-ml syringe with $20-\mathrm{G}$ needle

Beckman JS-4.2 and SW 55 rotors (or equivalents)

$13 \times 51-\mathrm{mm}$ silanized (APPENDIX $3 B$ ) and autoclaved polyallomer ultracentrifuge tube

Additional reagents and equipment for quantitating RNA (APPENDIX $3 D$ )

CAUTION: DEPC is a suspected carcinogen and should be handled carefully.

NOTE: The following solutions should be treated with DEPC to inhibit RNase activity: sodium acetate, water, and $5.7 \mathrm{M} \mathrm{CsCl}$ (UNIT 4.1).

NOTE: Carry out steps 1 to 4 at room temperature.

\section{Lyse the cells}

For monolayer culture

1a. Wash cells at room temperature by adding $5 \mathrm{ml}$ PBS per dish, swirling dishes, and pouring off. Repeat wash.

2a. Add $3.5 \mathrm{ml}$ guanidine solution for $\leq 10^{8}$ cells, dividing the solution equally between the dishes. The cells should immediately lyse in place. Recover the viscous lysate by scraping the dishes with a rubber policeman. Remove lysate from dishes using a 6-ml syringe with $20-\mathrm{G}$ needle. Combine lysates.

For suspension culture

1b. Pellet $\leq 10^{8}$ cells by centrifuging $5 \mathrm{~min}$ at $300 \times g$ ( $1000 \mathrm{rpm}$ in JS-4.2 rotor), room temperature, and discarding supernatant. Wash cells once at room temperature by resuspending the pellet in an amount of PBS equal to half the original volume and centrifuging. Discard supernatant.

2b. Add $3.5 \mathrm{ml}$ guanidine solution to the centrifuge tube.

3. Draw the resultant extremely viscous solution up and down four times through a 6-ml syringe with $20-\mathrm{G}$ needle. Transfer the solution to a clean tube.

It is critical that chromosomal DNA be sheared in this step in order to reduce viscosity. This allows complete removal of the DNA in the centrifugation step.
Preparation and Analysis of RNA

4.2.3

Supplement 36 


\section{Isolate the RNA}

4. Place $1.5 \mathrm{ml}$ of $5.7 \mathrm{M} \mathrm{CsCl}$ in a $13 \times 51-\mathrm{mm}$ silanized and autoclaved polyallomer ultracentrifuge tube. Layer $3.5 \mathrm{ml}$ of cell lysate on top of $\mathrm{CsCl}$ cushion to create a step gradient. The interface should be visible.

Silanizing the tube decreases the amount of material that sticks to the sides of the tube and thus decreases the level of contamination of the final RNA.

5. Centrifuge 12 to $20 \mathrm{hr}$ at $150,000 \times g(35,000 \mathrm{rpm}$ in $\mathrm{SW} 55$ rotor $), 18^{\circ} \mathrm{C}$. Set centrifuge for slow acceleration and deceleration in order to avoid disturbing the gradient.

6. Remove the supernatant very carefully (see Fig. 4.2.1). Place the end of the Pasteur pipet at the top of the solution and lower it as the level of the solution lowers. Leave $\sim 100 \mu \mathrm{l}$ in the bottom, invert the tube carefully, and pour off the remaining liquid.

There should be a white band of DNA at the interface-care must be taken to remove this band completely, as it contains cellular DNA.

7. Allow the pellet to drain 5 to $10 \mathrm{~min}$, then resuspend it in $360 \mu \mathrm{l}$ TES solution by repeatedly drawing the solution up and down in a pipet. Allow the pellet to resuspend 5 to $10 \mathrm{~min}$ at room temperature. Transfer to a clean microcentrifuge tube.

It is critical to allow ample time for resuspension of this pellet or the yield of RNA will be significantly decreased.

8. Add $40 \mu \mathrm{l}$ of $3 \mathrm{M}$ sodium acetate, $\mathrm{pH} 5.2$, and $1 \mathrm{ml}$ of $100 \%$ ethanol. Precipitate the RNA $30 \mathrm{~min}$ on dry ice/ethanol. Microcentrifuge 10 to $15 \mathrm{~min}$ at $4{ }^{\circ} \mathrm{C}$ and discard supernatant.

Figure 4.2.1 Technique for removing supernatant from a $\mathrm{CsCl}$ step gradient.

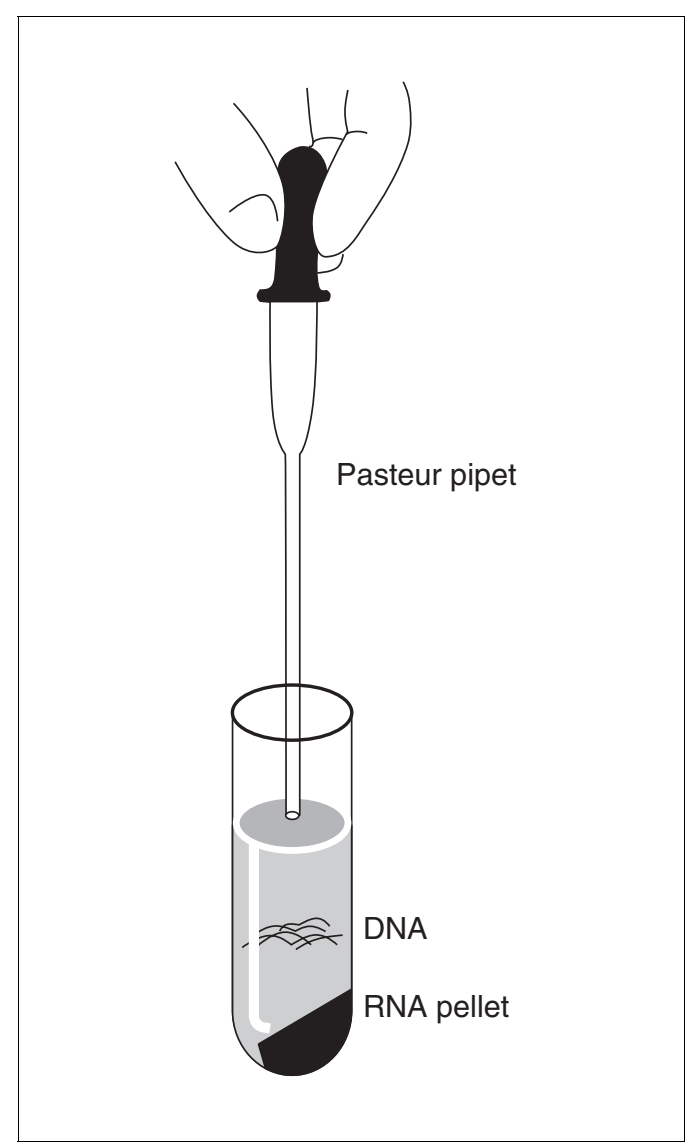


9. Resuspend the pellet in $360 \mu \mathrm{l}$ water and repeat step 8.

RNA dissolves more readily in water than in a salt solution.

\section{Quantitate the RNA}

10. Drain the pellet $10 \mathrm{~min}$ and dissolve in $\sim 200 \mu \mathrm{l}$ water. Quantitate by diluting $10 \mu \mathrm{l}$ to $1 \mathrm{ml}$ in alkaline water and reading the $A_{260}$ and $A_{280}$ (see Basic Protocol, step 10, and $A P P E N D I X 3 D$ ). Store RNA at $-70^{\circ} \mathrm{C}$ either as an aqueous solution or as an ethanol precipitate.

This protocol produces RNA that is clean enough for northern, S1, or SP6 analysis. If cleaner RNA is desired, step 7 can be modified with the following: After resuspending the pellet in TES solution, extract with $360 \mu \mathrm{l}$ of $4: 1(\mathrm{v} / \mathrm{v})$ chloroform/1-butanol and save the supernatant. Extract the chloroform by adding $360 \mu \mathrm{l}$ TES solution. Combine the supernatants, add 0.1 vol of $3 \mathrm{M}$ sodium acetate, $\mathrm{pH}$ 5.2, and ethanol precipitate as in step 8.

\section{CsCI PURIFICATION OF RNA FROM TISSUE}

Additional precautions must be taken when purifying RNA from tissue, as certain organs such as pancreas and spleen have very high endogenous levels of RNase. (Liver and intestine, however, have relatively low levels.) This protocol was originally described in Chirgwin et al. (1979) and modified by Richard Selden.

\section{Additional Materials (also see Alternate Protocol 1)}

Liquid nitrogen

Tissue guanidine solution (see recipe)

$20 \%$ (w/v) $N$-lauroylsarcosine (Sarkosyl)

Cesium chloride $(\mathrm{CsCl})$

Tissue resuspension solution (see recipe)

25:24:1 phenol/chloroform/isoamyl alcohol (UNIT 2.1)

24:1 chloroform/isoamyl alcohol

Tissuemizer

Sorvall SS-34 and Beckman SW 28 rotors (or equivalents)

SW 28 polyallomer tube silanized (APPENDIX $3 B$ ) and autoclaved

1. Rapidly remove tissue from the animal and quick-freeze it in liquid nitrogen.

The sample should be removed from the animal in pieces $\leq 2 \mathrm{~g}$ or it will be difficult to do the further workup.

RNA is very unstable in tissue once removed from the body so it is critical to quick-freeze the tissue. Placing the tissue in guanidine and then waiting to grind it will result in degraded $R N A$.

2. Add $20 \mathrm{ml}$ tissue guanidine solution for $\sim 2 \mathrm{~g}$ of tissue. Immediately grind the tissue in a tissuemizer with two or three 10-sec bursts for complete grinding.

Tissue guanidine solution, unlike the guanidine solution used in the Basic Protocol, lacks Sarkosyl. It is important that Sarkosyl not be present at this stage or a frothy mess will result.

3. Centrifuge $10 \mathrm{~min}$ at $12,000 \times g(10,000 \mathrm{rpm}$ in SS-34 rotor $), 12^{\circ} \mathrm{C}$.

4. Collect the supernatant and add 0.1 vol of $20 \%$ Sarkosyl. Heat 2 min at $65^{\circ} \mathrm{C}$.

5. Add $0.1 \mathrm{~g} \mathrm{CsCl} / \mathrm{ml}$ of solution, dissolve the $\mathrm{CsCl}$, then layer the sample over $9 \mathrm{ml}$ of $5.7 \mathrm{M} \mathrm{CsCl}$ in an SW 28 silanized, autoclaved polyallomer tube. Centrifuge overnight at $113,000 \times g(25,000 \mathrm{rpm}$ in SW 28 rotor $), 22^{\circ} \mathrm{C}$. 
6. Carefully remove the supernatant (see Alternate Protocol 1, step 6, and Fig. 4.2.1). Invert the tube to drain. Cut off bottom of tube (containing RNA pellet) and place it in a 50-ml plastic tube.

7. Add $3 \mathrm{ml}$ tissue resuspension buffer and allow pellet to resuspend overnight at $4^{\circ} \mathrm{C}$.

It is difficult to resuspend this pellet. Occasionally the sample may have to be left longer than overnight. The high concentrations of 2-mercaptoethanol and Sarkosyl prevent RNA degradation during this resuspension.

8. Extract the solution sequentially with 25:24:1 phenol/chloroform/isoamyl alcohol, then with 24:1 chloroform/isoamyl alcohol (see UNIT 2.1).

9. Add 0.1 vol of $3 \mathrm{M}$ sodium acetate, $\mathrm{pH} 5.2$, and $2.5 \mathrm{vol}$ of $100 \%$ ethanol. Precipitate RNA $30 \mathrm{~min}$ on dry ice/ethanol, microcentrifuge 10 to $15 \mathrm{~min}$ at $4^{\circ} \mathrm{C}$, discard supernatant, and resuspend in water. Quantitate the RNA and store (see Alternate Protocol 1, step 10).

\section{REAGENTS AND SOLUTIONS}

Use deionized, distilled water in all recipes and protocol steps. For common stock solutions, see APPENDIX 2; for suppliers, see APPENDIX 4.

\subsection{CsCl, DEPC-treated}

Dissolve $\mathrm{CsCl}$ in 0.1 M EDTA, pH 8.0. Add 0.002 vol DEPC, shake 20 to $30 \mathrm{~min}$, and autoclave. Weigh the bottle of solution before and after autoclaving and make up the weight lost to evaporation during autoclaving with DEPC-treated water (UNIT 4.1) to ensure that the solution is actually $5.7 \mathrm{M}$ when used.

\section{Denaturing solution}

Stock solution: Mix $293 \mathrm{ml}$ water, $17.6 \mathrm{ml}$ of $0.75 \mathrm{M}$ sodium citrate, $\mathrm{pH} 7.0$, and $26.4 \mathrm{ml}$ of $10 \%$ (w/v) $N$-lauroylsarcosine (Sarkosyl). Add 250 g guanidine thiocyanate and stir at $60^{\circ}$ to $65^{\circ} \mathrm{C}$ to dissolve. Store up to 3 months at room temperature. Working solution: Add $0.35 \mathrm{ml}$ 2-mercaptoethanol (2-ME) to $50 \mathrm{ml}$ of stock solution. Store up to 1 month at room temperature.

Final concentrations are $4 \mathrm{M}$ guanidine thiocyanate, $25 \mathrm{mM}$ sodium citrate, 0.5\% Sarkosyl, and $0.1 M$ 2-ME.

\section{Formamide}

Prepare freshly deionized formamide by stirring with $1 \mathrm{~g}$ AG 501-X8 ion-exchange resin (Bio-Rad) per $10 \mathrm{ml}$ formamide for $30 \mathrm{~min}$ and filter at room temperature. Alternatively, use a commercially available stabilized, ultrapure formamide (Formazol, Molecular Research Center).

\section{Guanidine solution}

Mix $550 \mathrm{ml}$ water with $1.64 \mathrm{~g}$ sodium acetate (anhydrous) and $472.8 \mathrm{~g}$ guanidine thiocyanate, and stir to dissolve, heating slightly (to $65^{\circ} \mathrm{C}$ ) if necessary to get the guanidine into solution. Add $15.4 \mathrm{mg}$ dithiothreitol (DTT) and $50 \mathrm{ml}$ of $10 \%(\mathrm{w} / \mathrm{v}$ ) $N$-lauroylsarcosine (Sarkosyl). Adjust $\mathrm{pH}$ to $\sim 5.5$ with acetic acid, dilute solution to 1 liter with water, and filter through a Nalgene filter. Store up to one month at room temperature.

Final concentrations are $4 \mathrm{M}$ guanidine isothiocyanate, $20 \mathrm{mM}$ sodium acetate, $0.5 \%$ Sarkosyl, and $0.1 \mathrm{mM} \mathrm{DTT}$.

\section{Sodium acetate, $2 \mathrm{M}$}

Add $16.42 \mathrm{~g}$ sodium acetate (anhydrous) to $40 \mathrm{ml}$ water and $35 \mathrm{ml}$ glacial acetic acid. Adjust solution to $\mathrm{pH} 4$ with glacial acetic acid and dilute to $100 \mathrm{ml}$ final with 
water (solution is $2 \mathrm{M}$ with respect to sodium ions). Store up to 1 year at room temperature.

\section{TES solution}

$10 \mathrm{mM}$ Tris. $\mathrm{Cl}, \mathrm{pH} 7.4$

$5 \mathrm{mM}$ EDTA

$1 \%(\mathrm{w} / \mathrm{v}) \mathrm{SDS}$

Store up to 1 year at room temperature

\section{Tissue guanidine solution}

Dissolve 590.8 g guanidine thiocyanate in $\sim 400 \mathrm{ml}$ DEPC-treated water (UNIT 4.1). Add $25 \mathrm{ml}$ of $2 \mathrm{M}$ Tris.Cl, pH 7.5, and $20 \mathrm{ml}$ of $0.5 \mathrm{M} \mathrm{Na}_{2}$ EDTA, pH 8.0 (APPENDIX 2). Stir overnight. Adjust the volume to $950 \mathrm{ml}$ and filter. Finally, add $50 \mathrm{ml}$ of 2-mercaptoethanol. Store up to three months at room temperature.

\section{Tissue resuspension solution \\ $5 \mathrm{mM}$ EDTA \\ $0.5 \%$ (w/v) $N$-lauroylsarcosine (Sarkosyl) \\ $5 \%(\mathrm{v} / \mathrm{v}) 2$-mercaptoethanol \\ Store up to 1 month at room temperature}

\section{Water-saturated phenol}

Dissolve $100 \mathrm{~g}$ phenol crystals in water at $60^{\circ}$ to $65^{\circ} \mathrm{C}$. Aspirate the upper water phase and store up to 1 month at $4^{\circ} \mathrm{C}$.

Do not use buffered phenol in place of water-saturated phenol.

\section{COMMENTARY}

\section{Background Information}

Guanidine thiocyanate is one of the most effective protein denaturants known. The use of guanidine to lyse cells was originally developed to allow purification of RNA from cells high in endogenous ribonucleases (Cox, 1968; Ullrich et al., 1977; Chirgwin et al., 1979).

The single-step method of RNA isolation described in the Basic Protocol is based on the ability of RNA to remain water soluble in a solution containing $4 \mathrm{M}$ guanidine thiocyanate, $\mathrm{pH} \mathrm{4,} \mathrm{in} \mathrm{the} \mathrm{presence} \mathrm{of} \mathrm{a} \mathrm{phenol/chloroform}$ organic phase. Under such acidic conditions, most proteins and small fragments of DNA (50 bases to $10 \mathrm{~kb}$ ) will be found in the organic phase while larger fragments of DNA and some proteins remain in the interphase. The fragmentation of DNA during homogenization helps to remove DNA from the water phase.

Since its introduction (Chomczynski and Sacchi, 1987), the single-step method has become widely used for isolating RNA from a large number of samples. In addition, the procedure permits recovery of total RNA from small quantities of tissue or cells, making it suitable for gene expression studies whenever the quantity of tissue or cells available is limited. The protocol presented here is an updated version of the original method that further shortens the time for RNA isolation. All commercial application of the method is restricted by a U.S. patent (Chomczynski, 1989).

The two alternate protocols present methods, based on the observed fact that RNA is denser than DNA or protein, for separating RNA from other cellular macromolecules in the guanidine lysate on a $\mathrm{CsCl}$ step gradient (Glisin et al., 1974). A method using hot phenol and guanidine thiocyanate has also been described (Ferimisco et al., 1982).

In Alternate Protocol 1, cultured cells are lysed with a solution that contains $4 \mathrm{M}$ guanidine as well as a mild detergent. This lysis is virtually instantaneous and the cells are thus rapidly taken from an intact state to a completely denaturing environment. In Alternate Protocol 2, tissues are homogenized in a guanidine solution without detergent. The protocols then take advantage of the fact that RNA can be separated from DNA and protein by virtue of its greater density. These protocols have received widespread use because they require very few manipulations. This increases the chance of producing intact RNA and reduces hands-on time for the experimenter. The disadvantage is that they require an ultracentrifuge and rotor, which generally limits the number of samples that can easily be processed
Preparation and Analysis of RNA 
Figure 4.2.2 Rat liver RNA $(5 \mu \mathrm{g})$ isolated using the Basic Protocol was electrophoresed in a formaldehyde $1 \%$ agarose gel containing ethidium bromide (left), transferred to a hybridization membrane and stained with methylene blue stain (Molecular Research Center; Herrin and Schmidt, 1988, right). Shown are 28S $(4.7 \mathrm{~kb})$ and $18 \mathrm{~S}(1.9 \mathrm{~kb})$ ribosomal RNAs, and $4 S$ to $5 S$ (0.10 to $0.15 \mathrm{~kb}$ ) RNA containing mix of tRNA and $5 S$ ribosomal RNA.

simultaneously. These protocols should be used when very high quality RNA from a limited number of samples is required.

There are several commercial kits for total RNA isolation utilizing guanidine-based methods, the majority based on the single-step method. They can be divided into two groups. The first group, exemplified by the RNA Isolation Kit from Stratagene, includes kits containing denaturing solution, water-saturated phenol, and sodium acetate buffer prepared according to the single-step protocol described here (see Basic Protocol). The use of these kits saves the time needed to make components of the single-step method, but at a substantially higher price. The second group of kits is based on a commercial version of the single-step method combining denaturing solution, phenol, and buffer in a single monophase solution. These kits offer an improved yield and shorter RNA isolation time (Chomczynski and Mackey, 1995). In this second group, the authors have tested and can recommend the following kits: Isogen (Nippon Gene), RNA-Stat 60 (TelTest), RNAzol B (Cinna Scientific), Tri-Pure Isolation Reagent (Boehringer Mannheim), TRI Reagent (Molecular Research Center), and TRIzol Reagent (Life Technologies). All the kits in the second group, except RNAzol B, allow simutaneous isolation of DNA and proteins from a sample used for RNA isolation.
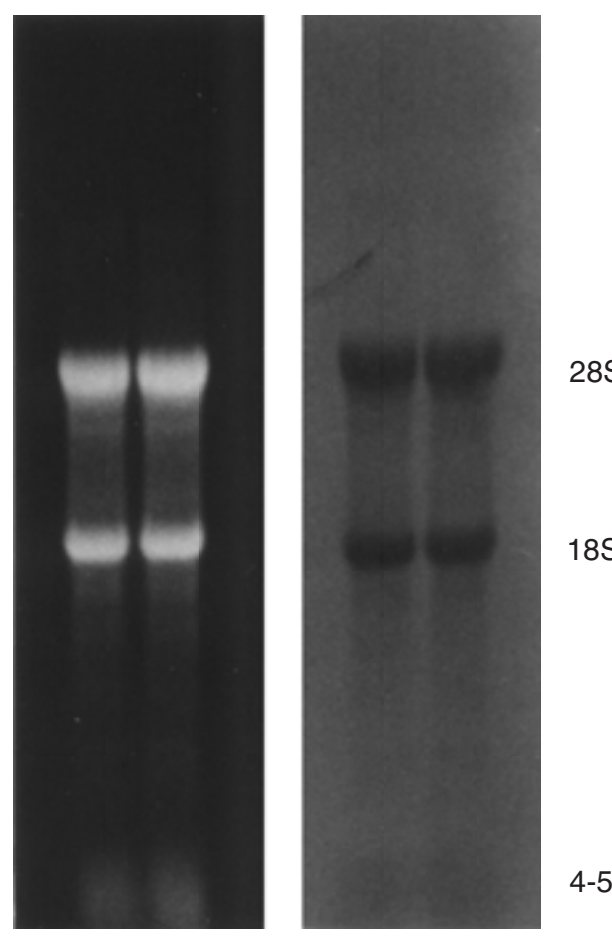

$28 S$

$18 S$

$4-5 S$

\section{Critical Parameters}

As with any RNA preparative procedure, care must be taken to ensure that solutions are free of ribonuclease. Solutions that come into contact with the RNA after adding the guanidine solution are all treated with DEPC, with the exception of the TES solution (Tris inactivates DEPC). Most investigators wear gloves at all times when working with RNA solutions, as hands are a likely source of ribonuclease contamination (see introduction to Chapter 4).

The two Alternate Protocols rely on a thorough separation of DNA and protein from RNA in the step gradient. The use of silanized tubes, as well as careful technique when removing the supernatant, are important. Finally, low yields may result from failing to allow sufficient time for resuspension of the RNA pellet after centrifugation. This pellet is not readily soluble, and sufficient time and vortexing should be allowed to dissolve it.

There are two important points to consider when using the single-step protocol. First, fresh tissue is preferable for RNA isolation. Alternatively, tissue should be frozen immediately in liquid nitrogen and stored at $-70^{\circ} \mathrm{C}$. In the latter case, tissue should be pulverized in liquid nitrogen and homogenized, using a Polytron or Waring blender, in denaturing solution without thawing. Second, it is important not to let the final RNA pellet dry completely, as that will greatly decrease its solubility. This is critical in 
all RNA isolation methods. Partially solubilized RNA has an $A_{260} / A_{280}$ ratio $<1$.6. Solubility of RNA can be improved by heating at $55^{\circ}$ to $60^{\circ} \mathrm{C}$ with intermittent vortexing or by passing the RNA solution through a pipet tip.

\section{Anticipated Results}

The single-step method yields the whole spectrum of RNA molecules, including small (4S to 5S) RNAs. The amount of isolated RNA depends on the tissue used for isolation. Typically, 100 to $150 \mu \mathrm{g}$ of total RNA is isolated from $100 \mathrm{mg}$ of muscle tissue and up to $800 \mu \mathrm{g}$ is isolated from $100 \mathrm{mg}$ of liver. The yield of total RNA from $10^{7}$ cultured cells ranges from 50 to $80 \mu \mathrm{g}$ for fibroblasts and lymphocytes and 100 to $120 \mu \mathrm{g}$ for epithelial cells. The $A_{260} / A_{280}$ ratio of the isolated RNA is $>1.8$.

The electrophoretic pattern of RNA isolated by the single-step method is exemplified in Figure 4.2.2 which shows the results of formaldehyde-agarose gel electrophoresis of rat liver RNA.

\section{Time Considerations}

The isolation of total RNA by the single-step method can be completed in $<4 \mathrm{hr}$. The procedure can be interrupted at one of the isopropanol precipitations or at the ethanol wash steps. Store samples at $-20^{\circ} \mathrm{C}$ if the procedure is interrupted at these steps. Avoid keeping samples in denaturing solution for $>30 \mathrm{~min}$.

In the alternate protocols, harvesting the RNA and setting up the gradient takes very little time ( $\sim 1 \mathrm{hr}$ for six samples) and is conveniently done in the evening, allowing the high-speed centrifuge run to go overnight. In a pinch, the guanidine cell lysate can be quick frozen in dry ice/ethanol and stored at $-70^{\circ} \mathrm{C}$. When the RNA is dissolved after the gradient, it can be stored as an ethanol precipitate indefinitely at any of the precipitation steps. The entire protocol requires 2 to $3 \mathrm{hr}$ of hands-on time for 6 to 12 samples.

\section{Literature Cited}

Chirgwin, J.J., Przbyla, A.E., MacDonald, R.J., and Rutter, W.J. 1979. Isolation of biologically active ribonucleic acid from sources enriched in ribonuclease. Biochemistry 18:5294.

Chomczynski, P. 1989. Product and process for isolating RNA. U.S. Patent \#4,843,155.

Chomczynski, P. 1992. Solubilization in formamide protects RNA from degradation. Nucl. Acids Res. 20:3791-3792.
Chomczynski, P. and Mackey, K. 1995. Substitution of chloroform by bromochloropropane in the single-step method of RNA isolation. Anal. Biochem. 225:163-164.

Chomczynski, P. and Sacchi, N. 1987. Single-step method of RNA isolation by acid guanidine thiocyanate-phenol-chloroform extraction. Anal. Biochem. 162:156-159.

Cox, R.A. 1968. The use of guanidine chloride in the isolation of nucleic acids. Methods Enzymol. 12:120-129.

Ferimisco, J.R., Smart, J.E., Burridge, K., Helfman, D.M., and Thomas, G.P. 1982. Co-existence of vinculin and a vinculin-like protein of higher molecular weight in smooth muscle. J. Biol. Chem. 257:11024-11031.

Glisin, V., Crkvenjakov, R., and Byus, C. 1974. Ribonucleic acid isolated by cesium chloride centrifugation. Biochemistry 13:2633.

Herrin, D.L. and Schmidt, G.W. 1988. Rapid, reversible staining of northern blots prior to hybridization. BioTechniques 6:196-200.

Puissant, C. and Houdebine, L.M. 1990. An improvement of the single-step method of RNA isolation by acid guanidine thiocyanate-phenolchloroform extraction. BioTechniques 8:148149.

Ullrich, A., Shine, J., Chirgwin, J., Pictet, R., Tischer, E., Rutter, W.J., and Goodman, H.M. 1977. Rat insulin genes: Construction of plasmids containing the coding sequences. Science 196:1313.

Wilfinger, W.W., Mackey, K. and Chomczynski, P. 1997. Effect of $\mathrm{pH}$ and ionic strength on the spectrophotometric assessment of nucleic acid purity. BioTechniques 22:474-476.

\section{Key References}

Chirgwin et al., 1979. See above.

Describes the use of guanidine to lyse cells.

Chomczynski and Sacchi, 1978. See above.

Original description of the single-step method.

Contributed by Robert E. Kingston

( $\mathrm{CsCl}$ isolation)

Massachusetts General Hospital and Harvard Medical School

Boston, Massachusetts

Piotr Chomczynski (single-step isolation) University of Cincinnati College of Medicine Cincinnati, Ohio

Nicoletta Sacchi (single-step isolation)

Laboratory of Molecular Oncology

National Cancer Institute

Frederick, Maryland
Preparation and Analysis of RNA

4.2.9 